Public Health

\section{Beware the mistletoe}

S tatistics on unintentional ingestions in children show that plants are consistently in the top ranks, and household plants are the commonest source. Fortunately, not all ingestions result in poisonings, although other factors such as allergy, contact dermatitis and foreign-body obstruction can lead to serious consequences. Although frequently overlooked, ingestion of pot soil treated with fertilizers and/or pesticides can also cause poisonings.

The topic of unintentional ingestions has traditionally focused on children, but the frequency with which such ingestions occur among elderly people suggests that the principles of safe houseplants should be extended to nursing homes as well.

The holiday season presents special challenges when it comes to keeping children safe. Normal routine is disrupted when families travel, especially when they stay in hotels or with relatives in environments that may not be childproofed. As visitors come and go, they often bring gifts, some of which are plants. To add to the recipe for disaster, the seasonal festivities mean that parents or caregivers are often distracted, which leaves youngsters with less than optimum supervision. Christmas plants are colourful and are usually attractively adorned with bright foil and ribbons. The most common Christmas plants - Christmas pepper (Capsicum annuum), holly (Ilex aquifolium), Jerusalem cherry (Solanum pseudocapsicum), mistletoe (Phoradendron serotinum) and yew (Taxus canadensis) - are toxic (Table I). ${ }^{1}$ Whereas infants will taste everything they encounter once they achieve hand-to-mouth coordination, toddlers and older children become more discriminating, giving the leaves a pass and going for the berries. Unfortunately, the colourful fruit or berries are the most toxic parts of these plants. To make matters worse, mistletoe and holly are sometimes used to decorate the dinner table and festive foods such as plum pudding.

Table 1: Signs and symptoms of ingestion of holiday plants

\begin{tabular}{|c|c|c|}
\hline Plant & Toxic part & Symptoms \\
\hline $\begin{array}{l}\text { Christmas pepper } \\
\text { (Capsicum annuum) }\end{array}$ & Fruit (pepper) & $\begin{array}{l}\text { Irritation and burning of the skin } \\
\text { (mucous membrane) after contact } \\
\text { with the fruit }\end{array}$ \\
\hline \multirow[t]{2}{*}{ Holly (Ilex aquifolium) } & \multirow[t]{2}{*}{$\begin{array}{l}\text { All parts, but } \\
\text { berries most toxic }\end{array}$} & $\begin{array}{l}\text { Mild-to-moderate gastrointestinal } \\
\text { irritation with ingestion of } 1 \text { or } 2 \\
\text { berries }\end{array}$ \\
\hline & & $\begin{array}{l}\text { Vomiting, diarrhea, electrolyte } \\
\text { loss, central nervous system effects } \\
\text { (e.g., depression) with ingestion of } \\
\text { greater numbers of berries }\end{array}$ \\
\hline $\begin{array}{l}\text { Jerusalem cherry } \\
\text { (Solanum } \\
\text { pseudocapsicum) }\end{array}$ & $\begin{array}{l}\text { All parts, but } \\
\text { berries most toxic }\end{array}$ & Same as for holly \\
\hline \multirow[t]{2}{*}{$\begin{array}{l}\text { Mistletoe (Phoradendron } \\
\text { serotinum) }\end{array}$} & \multirow[t]{2}{*}{ Berries } & $\begin{array}{l}\text { Mild gastroenteritis with ingestion } \\
\text { of several berries }\end{array}$ \\
\hline & & $\begin{array}{l}\text { Significant toxic effects, including } \\
\text { seizures and hallucinations, } \\
\text { reported after exposure to } \\
\text { concentrated extracts of the } \\
\text { European plant }\end{array}$ \\
\hline \multirow[t]{2}{*}{ Yew (Taxus canadensis) } & \multirow{2}{*}{$\begin{array}{l}\text { All parts except } \\
\text { seed capsule } \\
\text { (seeds must be } \\
\text { chewed to cause } \\
\text { toxic effects) }\end{array}$} & $\begin{array}{l}\text { Abdominal pain, vomiting, dilated } \\
\text { pupils, tachycardia }\end{array}$ \\
\hline & & $\begin{array}{l}\text { Serious toxic effects, including } \\
\text { seizures, coma and cardiac } \\
\text { arrhythmias, have been reported }\end{array}$ \\
\hline
\end{tabular}

Knowing what to do when an ingestion occurs is key. Often, parents panic and instinctively try to induce vomiting, although evacuating the stomach by any means, including ipecac, is no longer recommended as first aid for poisoning. ${ }^{2,3}$ Frequently, adults on the scene resort to the only means available, a finger down the back of the throat, which is ineffective in removing stomach contents. Instead, the first recommended action is to physically separate the child from the plant, which may include scooping debris from the mouth. The child's hands and face should be wiped with a damp cloth to remove any plant material that may cause a sensitivity reaction, since some plants usually not considered toxic will cause skin reactions. The next step, before doing anything else, is to consult the experts at the local poison control centre. Usually, this will save an unnecessary intervention, including a trip to the emergency department. Staff at the poison control centre will consider all the facts, including the plant's identity, the time since ingestion, the child's age, whether the incident was directly observed and whether there are any symptoms. They will also take into consideration previous experience with the behaviour of other children in the child's age group and previous poisonings with that particular plant. Proper plant identification is important because a variety of common names may be used to describe the same plant, and a plant may have different common names according to geography and even family custom. Finally, a plant's toxicity may be affected by the age of the plant and the growing conditions.

By virtue of the ease with which the environment can be controlled, poisonings by houseplants are the easiest to prevent. All parents should receive the following tips when preparing for their first baby, and these precautions should be reinforced as the family grows. Poison control centres can supply additional information on preventing plant poisonings.

\section{Keep only safe plants}

Serious toxic effects can be avoided simply by keeping only nontoxic plants in the house. This will ensure the safety 
not only of young children, but also any pets, especially kittens and puppies. There are dozens of attractive, readily available plants from which to choose: among the hanging plants, Swedish ivies (Plectranthus spp.); among upright plants, the jades (Crassula spp.), Dracaena and umbrella plants (Schefflera spp.; not to be confused with umbrella trees [Cyperus spp.]); for table plants, African violets (Saintpaulia ionantha) and coleus (Coleus blumei). Although most cacti are nontoxic, their sharp needles can cause discomfort to young children, who may try to grasp them. The very fine needles in particular are difficult to remove once embedded in the skin.

\section{If toxic plants are in the house, take special precautions}

Keep toxic plants out of reach, remembering that infants can climb before they can walk.

\section{Avoid the use of pesticides}

Commercial insecticidal soaps may contain ethanol. When necessary, use safe alternatives such a soap solution. A safe pesticide can be made at home us- ing a $2 \%$ solution of liquid dish soap in water. Although plant foods (fertilizers) are not highly toxic, the vomiting and diarrhea they can cause are unpleasant for both parent and child.

\section{Label your plants}

Ingested plant material can provoke symptoms such as salivation and emesis because of partial choking. These symptoms can be mistaken for a toxic effect if the identity of the plant is unknown. Plant labels will also be of help to other caretakers as well. If in doubt, consult a local florist or an online database. ${ }^{4}$

The much-maligned poinsettia (Euphorbia pulcherrima) was once implicated in the fatal poisoning of a child. However, this incident occurred in I9r9, in Hawaii, and the wild plant probably bore little resemblance to the popular plant cultivated domestically in North America today. There is probably no valid reason to banish this symbol of Christmas from homes with infants and toddlers or from nursing homes, ${ }^{5}$ although there is an established crossreactivity with the sap of this plant in latex-allergic individuals. ${ }^{6}$

The holiday season should be a time of enjoyment for all, so go ahead and decorate with poinsettias. And if you want to stand under the mistletoe, perhaps make it faux.

Jill Courtemanche

Robert G. Peterson

Department of Pediatrics

British Columbia's Children's

Hospital

Vancouver, BC

This article has been peer reviewed.

\section{REFERENCES}

I. Micromedex ${ }^{\circledR}$ healthcare series. Greenwood Village (CO): Thomson Micromedex. Updated periodically.

2. American Academy of Clinical Toxicology, European Association of Poison Centers and Clinical Toxicologists. Position paper: Ipecac syrup. J Toxicol Clin Toxicol 2004;42:133-43. Erratum in: J Toxicol Clin Toxicol 2004;42:1000.

3. Manoguerra AS, Cobaugh DJ. Guidelines for the Management of Poisoning Consensus Panel. Guideline on the use of ipecac syrup in the out-ofhospital management of ingested poisons. Clin Toxicol (Phila) 2005;43(I):I-IO.

4. Munro DB. Canadian poisonous plants information system. Ottawa: Canadian Biodiversity Information Facility; 2006. Available: www.cbif.gc.ca /pls/pp/poison?p_x=px (accessed 2006 Nov 3).

5. Runyon R. Toxicity of fresh poinsettia (Euphorbia pulcherrima) to Sprague-Dawley rats. Clin Toxicol I980;16:167-73.

6. American Latex Allergy Association [homepage]. Slinger (WI): The Association; 2006. Available: www.latexallergyresources.org (accessed 2006 Nov 3 ).

\section{Essential reading}

from CMA Media Inc.

- CMAJ

- Canadian Journal of Surgery

- Journal of Psychiatry \& Neuroscience

For information contact

CMA Member Service Centre

888 855-2555

cmamsc@cma.ca
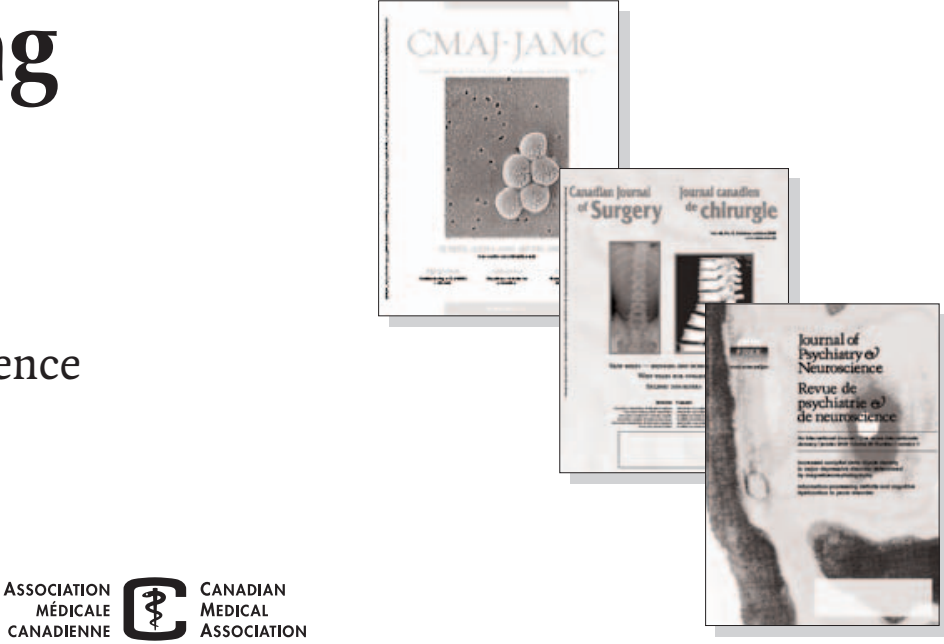